\title{
Gambaran Morfologi Eritrosit Packed Red Cell Berdasarkan Waktu Penyimpanan Di Bank Darah RSUP Dr. M. Djamil Padang
}

\author{
Risma Isti ${ }^{1}$, Zelly Dia Rofinda², Husni ${ }^{3}$
}

\begin{abstract}
Abstrak
Packed red cell (PRC) merupakan komponen darah terbanyak yang digunakan dalam transfusi dan dapat disimpan sekitar tiga puluh lima hingga empat puluh dua hari di bank darah. Penyimpanan PRC mengakibatkan jejas penyimpanan, yaitu perubahan morfologi eritrosit, deformabilitas, fragilitas osmotik, kemampuan untuk agregasi, dan viskositas intraseluler. Tujuan penelitian untuk mengetahui gambaran morfologi eritrosit PRC berdasarkan waktu penyimpanan. Penelitian ini merupakan penelitian deskriptif dengan rancangan potong lintang pada tujuh sampel PRC. Tiap sampel diperiksa pada hari penyimpanan ke nol, tujuh, empat belas, dua puluh satu, dan dua puluh delapan. Penelitian dilaksanakan mulai September 2016 hingga Agustus 2017. Pemeriksaan morfologi eritrosit dilihat dari sediaan hapus darah tepi dengan menghitung bentuk eritrosit abnormal per 1.000 eritrosit. Hasil penelitian disajikan dalam bentuk tabel distribusi frekuensi. Penelitian ini dilakukan pada tujuh sampel PRC yang berasal dari tujuh donor, terdiri dari enam donor laki-laki $(85,7 \%)$ dan satu orang donor perempuan (14,3\%). Rerata umur pendonor ialah 29 (5) tahun. Rerata kadar Hb pendonor ialah 14,5 (1,2) g/dL. Rerata kadar Hb sampel ialah 21,2 (2,5) $\mathrm{gr} / \mathrm{dL}$.Perubahan bentuk diskoid menjadi bentuk sfero-ekinosit didapatkan pada seluruh sampel penelitian. Perubahan bentuk eritrosit semakin meningkat seiring dengan waktu penyimpanan. Penyimpanan eritrosit mengakibatkan adanya perubahan morfologi eritrosit, yaitu perubahan bentuk eritrosit normal dari diskoid menjadi sfero-ekinosit. Penelitian lain diperlukan untuk mengetahui perubahan morfologi eritrosit dengan waktu penyimpanan berbeda lainnya dan adanya penelitian lanjutan untuk mengetahui korelasi antara parameter eritrosit dengan jejas penyimpanan.
\end{abstract}

Kata kunci: Morfologi eritrosit, packed red cell, waktu penyimpanan

\begin{abstract}
Packed red cells (PRCs) are the largest blood component used in transfusions and can be stored for thirty five until fourty two days in blood banks. PRC storage results in storage lesions, such as changes in erythrocyte morphology, deformability, osmotic fragility, ability to aggregate, and intracellular viscosity. The aim of this study was to examine erythrocyte morphology in PRC with different time storage. This was a descriptive study with cross sectional design with seven samples PRCs. Each PRC was examined on days zero, seven, fourteen, twenty-one, and twentyeight. The study was conducted from September in 2016 until August in 2017. Examination of erythrocyte morphology was seen from blood smears by counting abnormal erythrocyte shape per 1,000 erythrocytes. The results were presented in the frequency distribution tables. Seven PRCs samples from seven donors was involved in this study, which consist of six males (85,7\%) and one female (14,3\%). The mean age of the donors was 29(5) years. The mean $\mathrm{Hb}$ donor level was $14.5 \pm 1.2 \mathrm{~g} / \mathrm{dL}$. The mean $\mathrm{Hb}$ sample was $21.2 \pm 2.5 \mathrm{~g} / \mathrm{dL}$. During storage, all samples was changed from discoid form to sphero-ekinocytes. Changes in the shape of erythrocytes increased with different storage time. Storage of erythrocytes can induce changes erythrocyte morphology: from discoid into sphero-ekinocytes. Other studies are needed to determine the morphological changes of erythrocytes with other different storage times and determine the correlation between erythrocyte parameters and storage lesions.
\end{abstract}

Keywords: Erythrocyte morphology, packed red cell, time storage

Affiliasi penulis : 1. Pendidikan Dokter Spesialis Patologi Klinik Fakulltas Kedokteran Universitas Andalas/ RSUP Dr. M. Djamil Padang. 2. Bagian Patologi Klinik Fakulltas Kedokteran Universitas Andalas/ RSUP Dr. M. Djamil Padang 3. Bagian Patologi Klinik Fakulltas Kedokteran Universitas Andalas/ RSUP Dr. M. Djamil Padang

Korespondensi : Risma Isti email : isticoba1@yahoo.com Telp: 08126750215

\section{PENDAHULUAN}

Packed red cell (PRC) masih merupakan komponen darah terbanyak yang digunakan dalam transfusi. Packed red cell adalah produk darah yang paling penting dan dapat disimpan sekitar 35-42 hari di bank darah dengan penambahan larutan antikoagulan. Packed red cell dihasilkan dengan membuang plasma dari whole blood, yang kemudian disimpan pada suhu 2 hingga $6^{\circ} \mathrm{C} \cdot{ }^{1,2}$

Penelitian klinis banyak dilakukan dan menyarankan bahwa PRC dapat diberikan hingga 42 hari, namun dapat memberikan efek samping terhadap penerima transfusi sehingga menyebabkan tingginya angka morbiditas dan mortalitas. Kualitas PRC selama penyimpanan juga harus dijaga meskipun tetap terjadi perubahan dalam struktur, metabolik, dan biokimia 
yang disebut dengan storage lesion (jejas penyimpanan). ${ }^{2,3,4}$

Perubahan biomekanik eritrosit selama penyimpanan antara lain ialah perubahan bentuk, deformabilitas, fragilitas osmotik, kemampuan untuk agregasi, dan viskositas intraseluler. Perubahan spesifik morfologi eritrosit ialah perubahan dari bentuk bikonkaf menjadi bentuk ekinosit dengan tonjolan dan sferosit yang tidak dapat berubah. ${ }^{5}$

Perubahan bentuk eritrosit dapat disebabkan berkurangnya ATP pada eritrosit. Perubahan ATP pada eritrosit dapat menurun hingga $80-90 \%$ selama penyimpanan dan menyebabkan perubahan morfologi. Sejumlah besar sferosit irreversibel dan tetap bertahan meskipun kadar ATP ditingkatkan pada waktu delapan minggu penyimpanan eritrosit. ${ }^{5,6}$

Stres oksidatif juga berperan terhadap perubahan membran eritrosit. Reactive oxygen species (ROS) menyerang fraksi protein pada tingkat membran dan mengawali reaksi peroksidasi lipid yang menyebabkan kerusakan integritas membran dan kematian eritrosit. ${ }^{1,5}$

Berbagai penelitian tentang perubahan morfologi eritrosit akibat jejas penyimpanan telah banyak dilakukan dengan waktu penyimpanan yang berbeda. Sebuah penelitian meneliti perubahan eritrosit dalam tiga kelompok sampel PRC yang dipisah berdasarkan waktu penyimpanan 0-10 hari, 11-20 hari, dan lebih 21 hari. Penelitian ini membuktikan adanya korelasi antara abnormalitas eritrosit dan waktu penyimpanan. Eritrosit abnormal ditemukan setelah hari ke tujuh penyimpanan. ${ }^{7}$

Penelitian serupa meneliti sampel PRC dengan waktu penyimpanan $0,14,28$, dan 42 hari. Penelitian ini membuktikan bahwa eritrosit pada PRC yang disimpan selama 42 hari mengalami perubahan bentuk normal dari bentuk diskoid menjadi bentuk sferosit dengan penurunan rasio luas permukaan dibandingkan volume eritrosit. Sferosit dapat memudahkan terjadinya hemolisis dibandingkan dengan eritrosit normal. ${ }^{8}$,

Penelitian lainnya juga membuktikan adanya penurunan deformabilitas yang signifikan terhadap eritrosit $(53 \%)$ setelah dua minggu penyimpanan. Sferosit bahkan telah ditemukan pada hari ke lima setelah penyimpanan. ${ }^{9}$

Tujuan dari penelitian adalah untuk mengetahui gambaran morfologi eritrosit pada Packed red cell berdasarkan waktu penyimpanan yang berbeda $(0,7,14,21$, dan 28 hari) di Bank Darah RSUP Dr. M. Djamil Padang.

\section{METODE}

Penelitian ini merupakan penelitian deskriptif dengan rancangan potong lintang. Penelitian dilakukan di Bank Darah dan Instalasi Laboratorium Sentral RSUP Dr. M Djamil Padang dari bulan September 2016 - Agustus 2017. Sampel penelitian ialah tujuh kantong PRC dengan anti koagulan CPDA1 yang berasal dari tujuh donor. Sampel PRC kemudian disimpan di bank darah pada suhu $2-6^{\circ} \mathrm{C}$.
Tiap sampel PRC diperiksa pada hari penyimpanan ke-0, ke-7, ke-14, ke-21, dan ke-28 di bank darah dengan menilai perubahan bentuk eritrosit. Perubahan eritrosit dinilai dengan menganalisis sediaan hapus darah tepi yang diwarnai dengan pewarnaan Giemsa. Bentuk eritrosit abnormal seperti sferosit, ekinosit, ataupun fragmentosit dihitung per 1.000 eritrosit. Jumlah bentuk eritrosit abnormal dikategorikan sebagai normal, perubahan ringan, perubahan sedang ataupun perubahan berat seperti ditunjukkan tabel 1. ${ }^{10}$

Tabel 1. Perubahan Bentuk Eritrosit

\begin{tabular}{cc}
\hline $\begin{array}{c}\text { Jumlah Bentuk Eritrosit } \\
\text { Abnormal per } 1.000 \text { Eritrosit }\end{array}$ & Keterangan \\
$<5 \%$ & normal \\
$5-25 \%$ & ringan \\
$26-50 \%$ & sedang \\
$>50 \%$ & berat \\
\hline
\end{tabular}

\section{HASIL DAN PEMBAHASAN}

Penelitian ini dilakukan dengan pendonor penelitian sebanyak tujuh orang, terdiri dari enam orang pendonor laki-laki $(85,7 \%)$ dan satu orang pendonor perempuan (14,3\%). Rerata umur pendonor ialah 29 (5) tahun. Golongan darah pendonor didapatkan golongan darah B sebanyak tiga pendonor, golongan darah $\mathrm{O}$ sebanyak empat pendonor. Rerata kadar $\mathrm{Hb}$ pendonor ialah 14,5 $(1,2) \mathrm{g} / \mathrm{dL}$ (tabel 2).

Tabel 2. Karakteristik Pendonor Penelitian

\begin{tabular}{cccc}
\hline Karakteristik & Rerata (SD) & $\mathbf{n}$ & $\%$ \\
\hline Jenis kelamin & & 6 & 85,7 \\
Laki-laki & & 1 & 14,3 \\
Perempuan & & & \\
Umur & $29(5)$ tahun & & \\
Golongan darah & & & \\
$-\quad$ B & & 3 & 42,9 \\
$-\quad$ O & & 4 & 57,1 \\
Kadar Hb & $14,5(1,2) \mathrm{g} / \mathrm{dL}$ & & \\
\hline
\end{tabular}

Penelitian serupa pernah dilakukan dengan meneliti empat unit PRC dengan antikoagulan CPDA-1 yang diambil dengan teknik aferesis. Sampel PRC didapatkan dari dua donor dengan golongan darah $\mathrm{O}$ dan dua donor dengan golongan darah A. Penelitian lainnya juga dilakukan dengan meneliti unit PRC dengan antikoagulan CPDA-1 yang diperoleh dari 10 pendonor laki-laki dengan rerata usia pendonor ialah 25(2) tahun. Golongan darah pendonor didapatkan golongan darah A sebanyak dua orang, golongan darah B sebanyak enam pendonor, dan golongan darah O sebanyak enam pendonor.

Penelitian ini mendapatkan rerata kadar $\mathrm{Hb}$ sampel PRC berkisar 21,2 $(2,5) \mathrm{g} / \mathrm{dL}$ dengan kadar hematokrit berkisar 77,1 $(3,3) \mathrm{g} / \mathrm{dL}$ (tabel 3).

Tabel 3. Karakteristik Sampel Penelitian

\begin{tabular}{cc}
\hline Karakteristik & Rerata (SD) \\
\hline Kadar $\mathrm{Hb}$ & $21,2(2,5) \mathrm{gr} / \mathrm{dL}$ \\
Hematokrit & $77,1(3,3) \mathrm{g} / \mathrm{dL}$ \\
\hline
\end{tabular}

Pemeriksaan sampel PRC dilakukan dengan menilai adanya morfologi eritrosit pada sediaan hapus 
darah tepi. Morfologi eritrosit dinilai berdasarkan perubahan bentuk eritrosit abnormal per 1.000 eritrosit. Seluruh sampel masih dengan gambaran eritrosit normositik normokrom pada penyimpanan hari ke-0. Perubahan bentuk eritrosit normal dengan gambaran eritrosit anisositosis normokrom ditemukan selama penyimpanan (gambar 1 dan gambar 2).

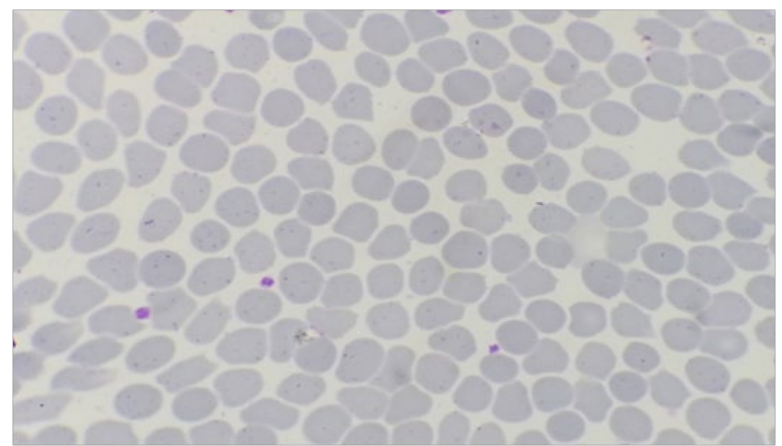

Gambar 1. Morfologi Eritrosit Penyimpanan Hari ke-0

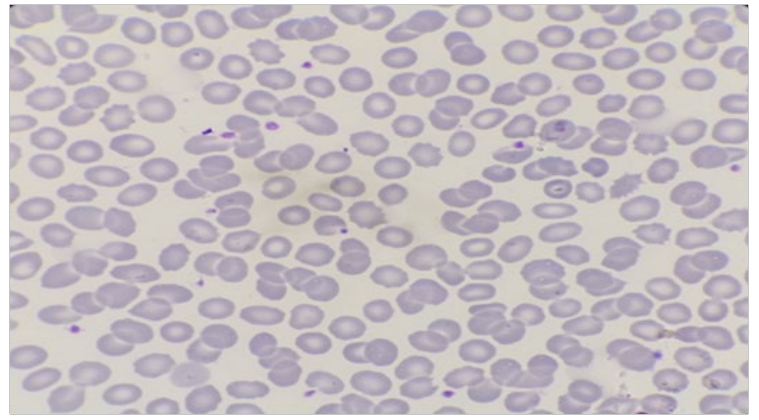

Gambar 2. Morfologi Eritrosit Penyimpanan Hari ke-28

Perubahan bentuk diskoid menjadi bentuk sfero-ekinosit ditemukan pada seluruh sampel penelitian (tujuh sampel PRC) hingga hari ke-28 penyimpanan

Perubahan bentuk eritrosit abnormal semakin meningkat seiring dengan pertambahan waktu penyimpanan. Perubahan eritrosit dinilai pada hari ke0, ke-7, ke-14, ke-21, dan ke-28 penyimpanan. Beberapa sampel telah mulai mengalami perubahan bentuk eritrosit normal mulai hari ke-7 penyimpanan, namun dengan jumlah $<5 \%$ (normal). Perubahan bentuk eritrosit normal ditemukan pada seluruh sampel pada penyimpanan hari ke-21, dengan jumlah $<5 \%$ (normal). Perubahan eritrosit ringan (5-25\%) ditemukan pada tiga sampel, sedangkan empat sampel lainnya masih dinyatakan normal hingga penyimpanan hari ke-28 (tabel 4).

Beberapa penelitian menyebutkan bahwa perbedaan jumlah eritrosit abnormal pada tiap sampel disebabkan oleh karakteristik donor yang dapat berdampak terhadap jejas penyimpanan. Karakteristik donor seperti genetik, jenis kelamin, fragilitas eritrosit, metabolit, akumulasi mikropartikel, sensitifitas terhadap stres oksidatif, dan kandungan antioksidan, sering disebut sebagai "efek variasi donor". ${ }^{11}$

Genetik dan parameter biologi yang dapat menyokong adanya mutasi terhadap penyakit hemolisis, hereditary spherocytosis, penyakit sel sabit, thalassemia atau defisiensi glukosa 6 fosfat, dapat merubah viskositas eritrosit atau kandungan antioksidan, sehingga memengaruhi eritrosit selama penyimpanan dan setelah ditransfusikan. Jenis kelamin juga berefek terhadap hemolisis yang terjadi selama penyimpanan. Beberapa penelitian menyebutkan bahwa eritrosit yang didapat dari donor laki-laki meningkatkan suseptibilitas terhadap stress induced hemolysis setelah penyimpanan, sedangkan jenis kelamin perempuan dan donor usia muda meningkatkan risiko kematian post transfusi, namun mekanisme pasti hal ini belum diketahui. ${ }^{12}$ Penelitian ini mendapatkan tiga sampel yang mengalami perubahan ringan setelah penyimpanan selama 28 hari berasal dari donor laki-laki.

Tabel 4. Jumlah Sampel dengan Eritrosit Abnormal Menurut Lama Penyimpanan

\begin{tabular}{|c|c|c|c|c|c|}
\hline \multirow{2}{*}{$\begin{array}{c}\text { Jumlah } \\
\text { eritrosit } \\
\text { abnormal per } \\
1.000 \text { eritrosit }\end{array}$} & \multicolumn{5}{|c|}{$\begin{array}{c}\text { Jumlah Sampel yang } \\
\text { Mengalami Perubahan }\end{array}$} \\
\hline & $\begin{array}{c}\text { Hari } \\
\text { ke - } \\
0 \\
\end{array}$ & $\begin{array}{c}\text { Hari } \\
\text { ke- } \\
7 \\
\end{array}$ & $\begin{array}{c}\text { Hari } \\
\text { ke - } \\
14 \\
\end{array}$ & $\begin{array}{c}\text { Hari } \\
\text { ke - } \\
21 \\
\end{array}$ & $\begin{array}{c}\text { Hari } \\
\text { ke- } \\
28 \\
\end{array}$ \\
\hline$<5 \%$ (normal) & 7 & 7 & 7 & 7 & 4 \\
\hline $5-25 \%$ (ringan) & 0 & 0 & 0 & 0 & 3 \\
\hline $\begin{array}{l}25-50 \% \\
\text { (sedang) }\end{array}$ & 0 & 0 & 0 & 0 & 0 \\
\hline$>50 \%$ (berat) & 0 & 0 & 0 & 0 & 0 \\
\hline
\end{tabular}

Karakteristik pendonor lainnya seperti kebiasaan merokok dan diet juga dapat memengaruhi kualitas eritrosit. Penelitian menyebutkan bahwa pada perokok dapat ditemukan adanya perubahan deformabilitas eritrosit, peningkatan fragilitas osmotik dan suseptibilitas terhadap oxidant-induced hemolysis. Kebiasaan diet, dan konsumsi makanan berlemak sebelum donasi dapat berefek terhadap karakteristik darah. Makanan berlemak berefek terhadap antioksidan plasma dan membran eritrosit, tingginya ROS, dan penurunan deformabilitas. Konsumsi alkohol berlebihan juga berefek terhadap peningkatan ROS. ${ }^{11}$ Hasil penelitian didapatkan bahwa sampel yang mengalami perubahan ringan setelah penyimpanan selama 28 hari berasal dari donor yang merupakan perokok, namun tidak ada keterangan lain seperti sejak kapan mulai merokok ataupun konsumsi rokok per hari.

Efek variasi donor lainnya seperti variabilitas usia eritrosit donor, kadar ATP, $\mathrm{pH}$ saat diambil juga berpengaruh terhadap kualitas eritrosit selama penyimpanan. Mekanisme glikolitik selama penyimpanan melibatkan ATP. Penurunan kadar ATP akan berefek terhadap perubahan morfologi eritrosit. 13 Pada penelitian ini tidak diketahui berapa umur eritrosit saat diambil, ataupun kadar ATP dan $\mathrm{pH}$ pada hari ke- 0 penyimpanan.

Perubahan eritrosit selama penyimpanan akan menghasilkan eritrosit dengan efektifitas rendah dan manfaat yang kurang terhadap perbaikan oksigenasi jaringan. Beberapa penelitian menyebutkan 
adanya oksigenasi jaringan yang tidak baik akibat transfusi eritrosit simpan. Penurunan $\mathrm{pH}$ mukosa lambung dan hipoksia splankhnik terjadi setelah transfusi eritrosit yang disimpan lebih dari 15 hari. ${ }^{5}$ Penelitian lainnya meneliti efek transfusi pada 400.000 pasien yang mayoritas dirawat di ICU dan menjalani operasi jantung. Penelitian ini menunjukkan angka mortalitas yang lebih tinggi terdapat pada pasien yang menerima transfusi eritrosit dengan waktu simpan yang lama. ${ }^{6,14}$ Darah simpan lebih dari 14 hari juga berhubungan dengan peningkatan angka mortalitas. ${ }^{15}$ Penelitian ini memiliki beberapa keterbatasan, yaitu hanya mengukur perubahan PRC simpan hingga 28 hari, sementara dengan anti koagulan CPDA-1 PRC dapat bertahan hingga 35 hari, dan tidak menganalisis perubahan PRC simpan per hari.

\section{SIMPULAN}

Penyimpanan eritrosit mengakibatkan adanya perubahan morfologi eritrosit, yaitu perubahan bentuk eritrosit normal dari diskoid menjadi sfero-ekinosit.

\section{SARAN}

Penelitian lain diperlukan untuk mengetahui perubahan morfologi eritrosit dengan waktu penyimpanan berbeda lainnya. Penelitian lanjutan juga diperlukan untuk mengetahui korelasi antara parameter eritrosit dengan jejas penyimpanan.

\section{DAFTAR PUSTAKA}

1. Deyhim MR, Navabi Z, Jalili MA, Maghsoudloo M, Khoshnaghsh F. Alternation in Erythrocyte Enzyme Antioxidant Activity During Blood Storage. Iranian Journal of Blood and Cancer Volume 6 No 2. 2014. pp: 69-74. Diunduh pada Oktober 2016.

2. Alessandro AD, Limbruno G, Grazzini G, Zolla L. Red Blood Cell Storage: The Story So Far. Blood Transfusion Volume 8. 2010. pp: 82-88. Diunduh pada September 2016.

3. Adias TC, Igwe BM, Jeremiah ZA. Storage Related Haematological and Biochemical Changes of CPDA-1 Whole Blood in A Resource Limited Setting. Journal Blood Disorders \& Transfusion Volume 3 Issue 3. 2012. pp: 1-4. Diunduh pada Agustus 2016.

4. Bhaduri B, Kandel M, Brugnara C, Tangella K, Popescu G. Optical Assay of Erythrocyte Function in Banked Blood. Scientific Reports Volume 4, 2014. pp: 1-6. Diunduh pada Agustus 2016.

5. Kor DJ, Buskirk CMV, Gajic O. Red Blood Cell Storage Lesion, Bosnian Journal Of Basic Medical Sciences Volume 9. 2009. pp: 21-27. Diunduh pada Agustus 2016.

6. Cluitmans JCA, Hardeman MR, Dinkla S, Brock R, Bosman GJGM. Red Blood Cell Deformability During Storage: Towards Functional Proteomics and Metabolomics In The Blood Bank. Blood Transfus Volume 10 Suppl 2. 2012. pp: 12-18. Diunduh pada September 2016.

7. Esper RC, Cordova CAC, Cordova JRC, Cordova LDC. Storage-Induced Morphological Changes in Erythrocytes. Rev Invest Med Sur Mex volume 19
(1). 2012. pp: 10-14. Diunduh pada Agustus 2016.

8. Mustafa I, Marwani AA, Nasr KM, Kano NA, Hadwan T. Time Dependent Assesment of Morphological Changes : Leukodepleted Packed Red Blood Cell Stored in SAGM. BioMed Research International Volume 2016. 2016. pp: 1-7. Diunduh pada Agustus 2016.

9. Park HJ, Ji M, Lee SY, Kim K, Sohn YH, Jang S et al. Alterations in Cell Surface Area and Deformability of Individual Human Red Blood Cells In Stored Blood. Medical Physics Volume 5. 2015. pp: 1-15. Diunduh pada Agustus 2016.

10. Palmer L, Briggs C, McFadden S, Zini G, Burthem J, Rozenberg $G$ et al. ICSH Recommendations For The Standardization Of Nomenclature And Grading Of Peripheral Blood Cell Morphological Features. International Journal Of Laboratory Hematology Volume 37. 2015. pp: 287-303. Diunduh pada Februari 2017.

11. Tzounakas VL, Kriebardis AG, Papassideri IS, Antonelou MH. Donor-Variation Effect On Red Blood Cell Storage Lesion: A Close Relationship Emerges. Proteomics Clin. Appl Volume 56. 2016. pp: 1-14. Diunduh pada Juli 2017.

12. Kanias T, Lanteri MC, Page GP, Guo Y, Endres $\mathrm{SM}$, Stone $\mathrm{M}$ et al. Ethnicity, Sex, and Age are Determinants of Red Blood Cell Storage and Stress Hemolysis: Results of The REDS-III RBCOmics Study. Blood Advances Volume 1 No 15. 2017. pp: 22-23. Diunduh pada Agustus 2016.

13. Mailo SR. Storage Time and Interdonor's Variability Effect on Red Blood Cell Storage Lesion. UC San Diego Electronic Theses and Dissertations. 2014. pp: 4-5. Diunduh pada September 2016.

14. Cohen B, Matot I. Aged Erythrocytes: A Fine Wine or Sour Grapes? British Journal Of Anasthaesia Volume 111 (S1). 2013. pp: 62-70. Diunduh pada Juni 2016.

15. Qu L, Triulzi DJ. Clinical Effects of Red Blood Cell Storage. Cancer Control. 2015. pp: 26-29. Volume 22 No. 1. Diunduh pada Agustus 2016. 